\title{
Biological aspects of the Sack fish, Neoepinnula orientalis from southeastern Arabian Sea
}

\author{
N. Beni, U. Ganga* and K. S. Sobhana \\ ICAR-Central Marine Fisheries Research Institute, P.B. No 1603, Kochi -682 018, Kerala, India. \\ *Correspondence e-mail: ganga66@rediffmail.com
}

Received: 12 Feb 2016, Accepted: 15 July 2017, Published: 30 July 2017

\section{Short Communication}

\begin{abstract}
Biological aspects of Neoepinnula orientalis is reported based on samples collected from the by-catch landed by deep-sea trawlers at Cochin Fisheries Harbor. The estimated length at first maturity $(\mathrm{Lm})$ of females was $195 \mathrm{~mm}$ and males $192 \mathrm{~mm}$. Diet study indicated strongly carnivorous feeding habit dominated by fishes (55\%), cephalopods (27\%) and crustaceans (18\%) occurring in deeper waters. Absolute fecundity ranged from 12,149 to $1,54,556$ with relative fecundity 737 eggs/g body weight and indicated a multiple spawning habit.
\end{abstract}

Keywords: Neoepinnula orientalis, diet, reproduction, life history

\section{Introduction}

Fishes of the family Gempylidae (Snake mackerels) usually inhabit deep waters at depth ranges from 200 to $500 \mathrm{~m}$ and Neoepinnula orientalis (Gilchrist and Von Bonde, 1924) is commonly observed in the deep sea trawl by-catch along the
Indian coast. The Snake mackerel fishery landed at Tuticorin has been reported by Balasubramanian and Abdussamad (2007). Reports from exploratory surveys (Sivakami, 1990; Khan et al., 1996; Jayaprakash et al., 2006; Venu and Kurup 2006; Karuppasamy et al., 2008 and Sreedhar et al., 2013) indicate its occurrence along the Indian coast. Results of the exploratory surveys in the Arabian Sea indicate that the species is abundant in $7^{\circ}-12^{\circ} \mathrm{N}$ latitudes with catch rates varying from $6-11 \mathrm{~kg} / \mathrm{h}$ (Venu and Kurup, 2006) to $67 \mathrm{~kg} / \mathrm{h}$ (Mathew et al., 1993). Although, initially not considered as a table fish, demand for snake mackerels have since grown in the domestic market (Abdussamad et al., 2011) making it a potential target for fishing as exploitation of deep-sea resources develop in India. Hence baseline data on the fishery aspects and life history traits of the species need to be documented.

\section{Material and methods}

Samples were collected from the trawl by-catch at Cochin Fisheries Harbor during the period of 2009-2010. From monthly samples, 1,309 specimens were individually analysed for length frequency distribution and their biology recorded. Stomachs were visually categorized based on the fullness of the gut and classified into active (1/ 2 to full) and poor feeding (1/4 to traces) condition. Empty stomachs were 
recorded separately. Occurrence method (Hynes, 1950) was used to determine preferred prey items using stomachs which contained food $(n=473)$. Macroscopic assessment of gonads for different stages of maturity stage, using egg size, gonado somatic index and gonad appearance was made. Fishes with stage $V$ and $V I$ gonads, classified as ripe $(n=26$, total length $215-265 \mathrm{~mm}$ ) were used for estimation of fecundity by gravimetric method. Length at first maturity $\left(L_{m}\right)$ was estimated using logistic curve method (King, 1996) with fish of size range $135-280 \mathrm{~mm}(\mathrm{n}=275)$. Length-weight relationship was determined as: $W=a L^{b}$ where, $W=$ weight of fish $(\mathrm{g})$ and $\mathrm{L}=$ length of fish $(\mathrm{mm})$.

\section{Results and discussion}

\section{Length frequency}

The size distribution of males ranged from 140 to $220 \mathrm{~mm}$ and females from 130 to $280 \mathrm{~mm}$. Females of comparatively larger size range than that of males were available in the by-catch. Females dominated among the fishes having size $>220 \mathrm{~mm}$ (Fig.1). Length weight relationship showed allometric growth with no significant differences among the sexes. The pooled length weight relation $\mathrm{W}=\mathrm{a} \mathrm{L}^{\mathrm{b}}$ was determinated as: $\mathrm{W}=$ $0.000001 \mathrm{~L} 3.230\left(\mathrm{r}^{2}=0.7736\right)$

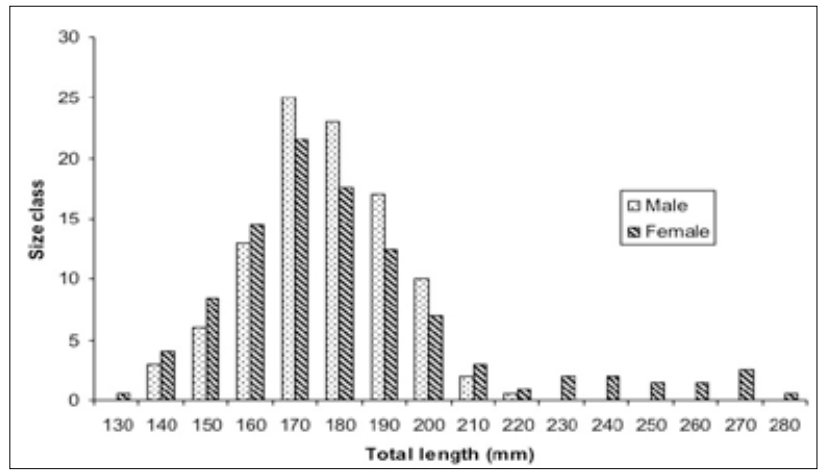

Fig. 1. Size distribution of males and females of Neoepinnula orientalis

\section{Diet studies}

Fishes (55\%) constituted the major food component followed by cephalopods $(27 \%)$ and crustaceans $(18 \%)$. Fishes were abundant in August to November, cephalopods during December, January and March and crustaceans in May (Fig. 2). N. orientalis is strongly carnivorous with squids, fishes, octopuses, shrimps, ribbonfish and myctophid as common food items (Fig. 3). Off Tuticorin coast, a diet dominated by myctophids and mesopelagic fishes was reported by Abdussamad et al. (2011), while Karuppasamy et al. (2008) reported myctophids and shrimps as dominant. However, in the present study the oceanic squid Sthenoteuthis oualaniensis (36\%) and ribbon fishes $25(\%)$ formed the single largest diet components which could be due to the increased availability

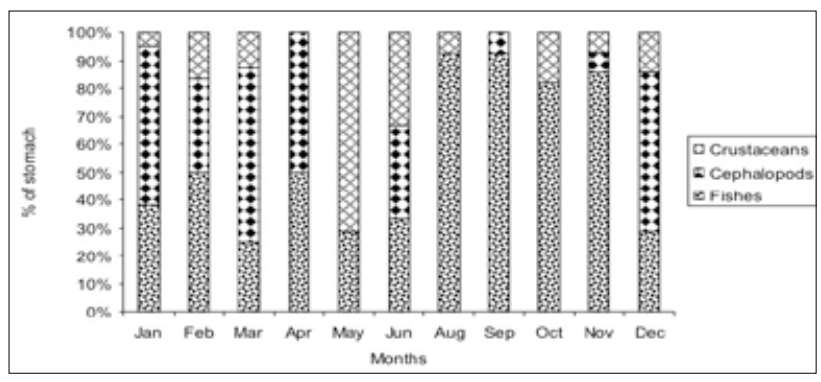

Fig. 2. Percentage composition of different groups in the stomach content of $N$. orientalis

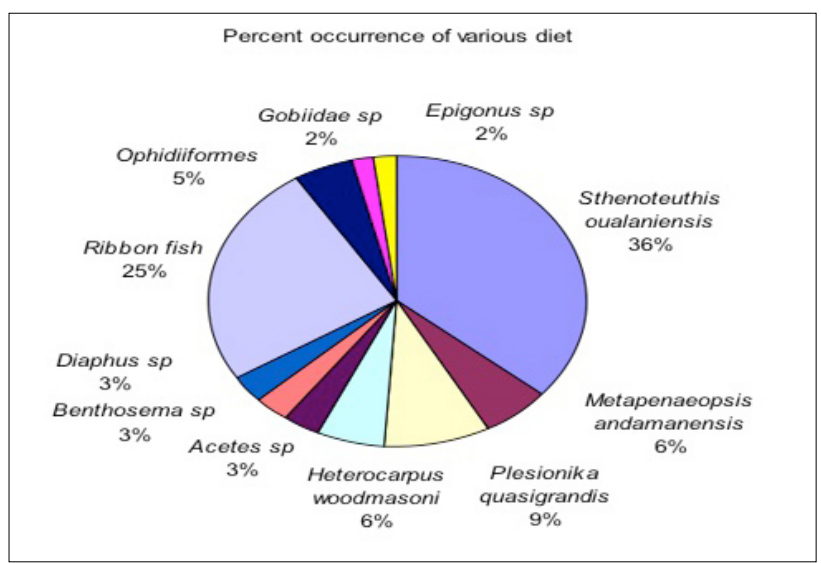

Fig. 3. Percentage occurrence of various diet component in $N$. orientalis

of these resources in the Arabian Sea (FAO, 2011) as compared to Gulf of Mannar ecosystem in the Bay of Bengal. The study thus indicates that the species has a broad diet width and accepts fishes, shrimps and molluscs as food, when available which becomes a favorable factor while scoring the general resilience capacity of the species.

\section{Reproductive biology}

Length at first maturity $\left(L_{m}\right)$ was estimated as $192 \mathrm{~mm}$ in males and $195 \mathrm{~mm}$ in females (Fig. 4) which is slightly higher than the size of $180 \mathrm{~mm}$ (sexes pooled) estimated in the Gulf of Mannar ecosystem.

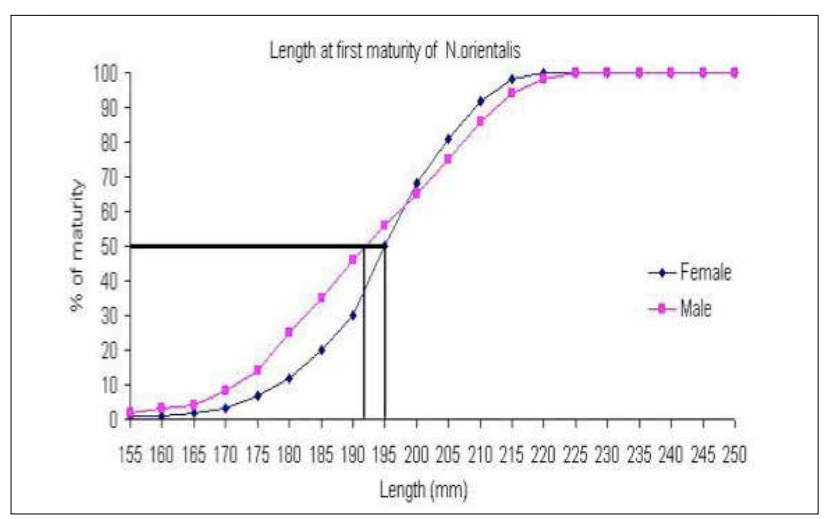

Fig. 4. Length at first maturity of $N$. orientalis 
Gonadosomatic index indicated stage I and stage II are with immature ova; stage III, IV, and V are mature stage; VI ripe and stage VII spent. High gonadosomatic indices were recorded for both male and female in ripe mature stages with females having higher GSI then males. GSI of females nearly doubled when they passed from maturing to ripe stage, but the increase in GSI was comparatively lower in males (Fig. 5).

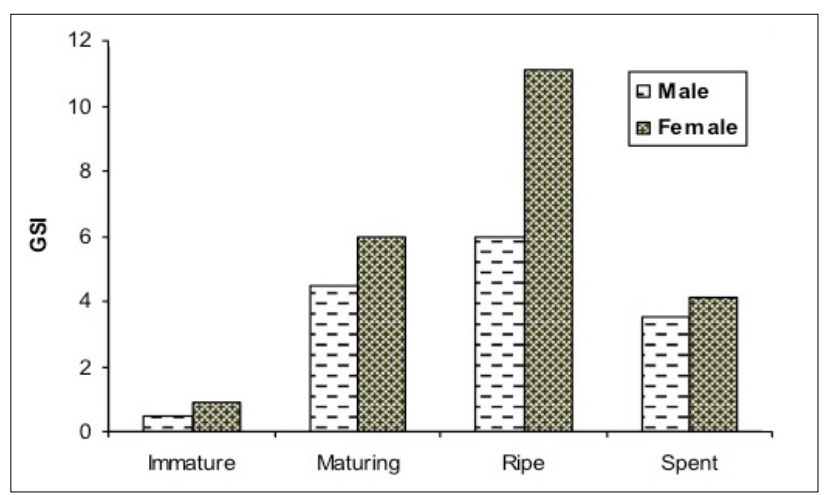

Fig. 5. GSI during various maturity stages of N.orientalis

Macroscopically ripe ovaries were whitish in colour and maximum spawning activity as observed from occurrence of ripe gonads was during November to December (Fig. 6). Immature fishes dominated in May. Abdussamad et al. (2011) reported that mature fishes occur in the Gulf of Mannar during December to March which is similar to the observation in the present study.

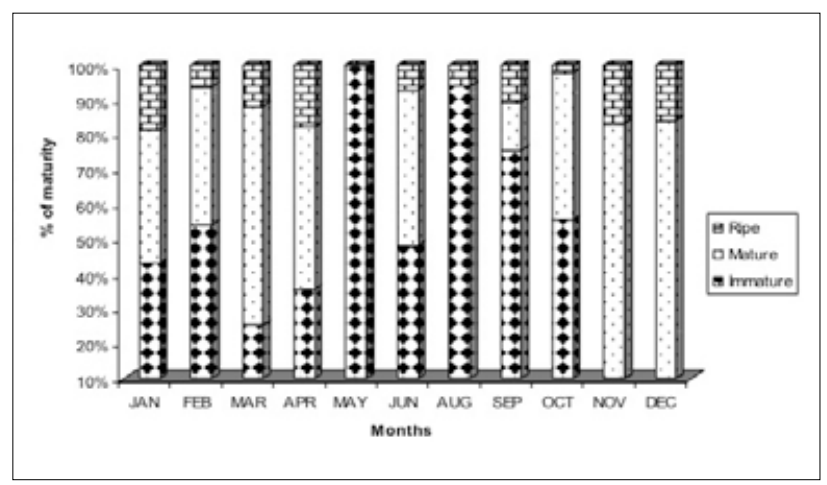

Fig. 6. Maturity stages recorded in $N$. orientalis during different months
Absolute fecundity of ripe female fishes ranged from 12,149 to $1,54,556$ eggs. The relative fecundity (fecundity/g body weight) was between 501 to 972 with a mean value of 737 eggs. Abdussamad et al. (2011) had estimated a relative fecundity of 794 eggs in the Gulf of Mannar. Fecundity of snake mackerel, a deep sea species is thus comparable to species with high fecundity and rapid population turnover rates like mackerel found in the pelagic realm. Relation between body length, gonad weight and body weight to fecundity indicated that total length had strongest relation to fecundity $\left(\mathrm{r}^{2}=0.8\right)$ (Fig.7) compared to gonad weight $\left(\mathrm{r}^{2}=\right.$ 0.2 ) and body weight $\left(r^{2}=0.15\right)$. Regulating the size of fish

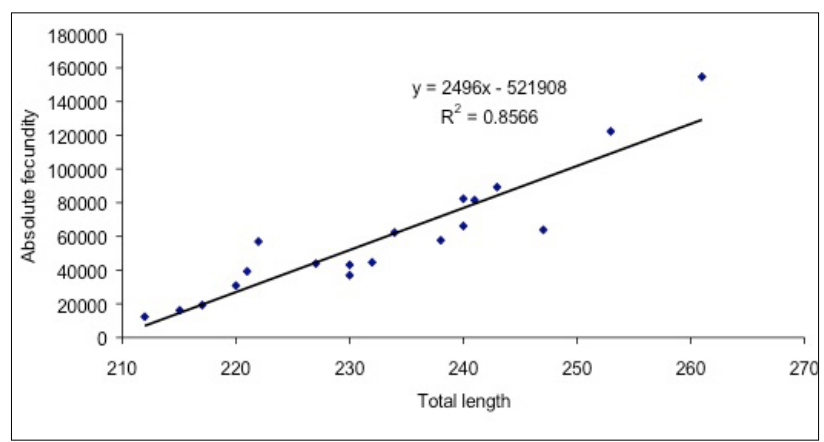

Fig. 7. Relationship between total length and absolute fecundity of N. orientalis

caught will therefore be an important fisheries management tool for this species if fisheries targeting the deeper water resources develop in the future.

Egg size of $0.4 \mathrm{~mm}$ was observed in the first stage of maturity and $0.7 \mathrm{~mm}$ in fully ripe stages (Table. 1). Histological examination of ripe ovaries revealed presence of three batches of oocytes (Fig. 8 and 9) that contained immature oocytes $(<0.3 \mathrm{~mm})$, mature oocytes $(0.3 \mathrm{~mm}-0.7 \mathrm{~mm})$, and ripe oocytes $(>0.7 \mathrm{~mm}$ ) which indicated that the fish is a multiple spawner.

High relative fecundity and multiple spawning nature indicate potential for high population turnover rates. Catch

Table 1. Gonad stages in female N. orientalis

\begin{tabular}{llllll}
\hline Gonad condition & Stage & Ova diameter range & Ova diameter mode & Ovary condition & GSI \\
\hline Immature & I & $0.03-0.09 \mathrm{~mm}$ & $0.07 \mathrm{~mm}$ & Ovary very small, colorless, eggs not visible to naked eye. & $0.5-0.9$ \\
\hline Immature & II & $0.05-0.2 \mathrm{~mm}$ & $0.1 \mathrm{~mm}$ & Translucent, ovary pinkish red in colour. & \\
\hline Developing & III & $0.05-0.4 \mathrm{~mm}$ & $0.2 \mathrm{~mm}$ & Ovary whitish in colour with blood capillaries, eggs visible as whitish granules. & $4.5-6$ \\
\hline Early mature & IV & $0.2-0.6 \mathrm{~mm}$ & $0.4 \mathrm{~mm}$ & Opaque white ovaries with prominent blood vessels. Eggs visible with naked eyes. \\
\hline Mature & $\mathrm{V}$ & $0.3-0.7 \mathrm{~mm}$ & $0.6 \mathrm{~mm}$ & Opaque white ovaries filling body cavity. & $6-11.08$ \\
\hline Ripe & $\mathrm{VI}$ & $0.1-0.8 \mathrm{~mm}$ & $0.7 \mathrm{~mm}$ & Opaque white ovaries with prominent round eggs. \\
\hline Spent & VII & $0.4-0.8 \mathrm{~mm}$ & $0.7 \mathrm{~mm}$ & Dull whitish flabby ovaries with a few opaque eggs. & $3.5-4.1$ \\
\hline
\end{tabular}




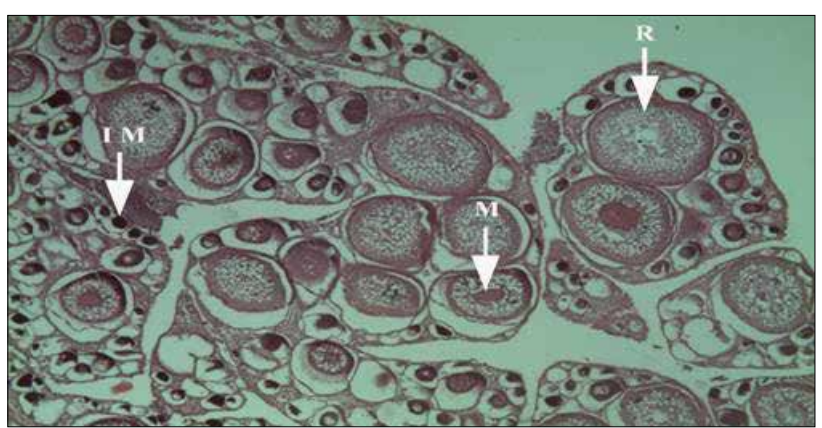

Fig. 8. Histological section of ripe gonad of N.orientalis: IM -Immature eggs, M- Mature eggs, R-Ripe eggs ( $H \& E, x 40$ )

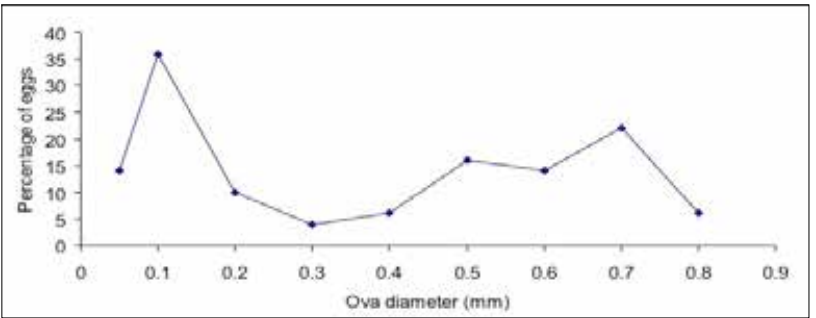

Fig. 9. Ova-diameter of ripe gonad in $N$. orientalis

rates in exploratory surveys and by-catch estimates also indicate its relatively high abundance in Indian seas. The results of the study suggest that this species is one of the potential fishery resources that can be exploited from beyond $200 \mathrm{~m}$ depth zone.

\section{Acknowledgements}

We thank CMLRE (Ministry of Earth Sciences, Govt. of India) for financial support and Director, ICAR - CMFRI, Kochi for providing facilities to carry out the research work.

\section{References}

Abdussamad, E. M., T. S. Balasubramaniam, N. Beni, O. M. M. J. Habeeb Mohamed and K. Jeyabalan. 2011. Snake mackerel fishery of the Tuticorin Coast of Gulf of Mannar with emphasis on population characteristics of the sackfish Neoepinnula orientalis (Gilchrist \& von Bonde 1924). Indian J. Fish., 58 (3): 9-12.

Balasubramanian, T. S. and E. M. Abdussamad. 2007. On the occurrence and fishery of fishes of the family Gempylidae along the Tuticorin Coast in Gulf of Mannar Mar. Fish. Infor. Serv. T\& E. ser., 2: 191 pp.

FAO, 2011. Fisheries and Aquaculture Report No. 971, FAO, 58 pp.

Feroz Khan, M., P. U. Zacharia, N. Nandakumaran, S. Mohan, M. R. Arputharaj, D. Nagaraja and P. Ramakrishnan. 1996. Catch, abundance and some aspects of biology of deep sea fish in the southeastern Arabian Sea. Proc. Second Workshop on Scient. results FORV Sagar Sampada., p. 331-346.

Hynes, H. B. N. 1950. The food of fresh water stickle backs. (Gasterosteus aculeatus and pygosteus pungititus) with a review of methods used in studies of the food of fishes. J. Anim. Ecol., 19 (1): 36-58.

Jayaprakash, A. A., B. Madhusoodana Kurup, U. Sreedhar, S. Venu. Divya Thankappan, V. Anish, Pachu, Hashim Manjebrayakath, Paul Thampy and Siva Sudhakar. 2006. Distribution, diversity, length-weight relationship and recruitment pattern of deepsea finfishes and shell fishes in the shelf-break area off south west Indian EEZ. J. Mar. Biol. Ass. India, 48(1): 56-67.

Karuppasamy, P. K., K. Balachandran, Simmy George, S. Balu, Vimala Persis and N. G. Menon. 2008. Food of some deep sea fishes collected from the eastern Arabian Sea. J. Mar. Biol. Ass. India, 50(2): 134-138.

King, Michael. 1996, Fishery biology, assessment and management, Blackwell publishers, USA, $382 \mathrm{pp}$.

Mathew, G., P. Jayasankar, S. Sivakami and J. Narayanaswamy. 1993. Observation on the distribution and biology of a few bathypelagic fishes from the south west coast of India. Indian J. Fish., 40(4): 207-212.

Sreedhar, U., G. V. S. Sudhakar, and B. Meena Kumari. 2013. Length weight relationship of deep-sea demersal fishes from the Indian EEZ. Indian J. Fish, 60(3): 123-125.

Sivakami, S. 1990. Observations on the demersal fishery resources of the coastal and deep sea areas of the exclusive economic zone of India. Proc. First Workshop Scient. Resul. FORV Sagar Sampada, 5-7 June 1989:215-231.

Venu, S. and B. Madhusoodhana Kurup. 2006. Distribution and biology of deep-sea fishes Neoepinnula orientalis Gilchrist and Vonbonde 1924 and Psenopsis squamiceps Lloyd, 1909 from west coast of Indian EEZ. J. Mar. Biol. Ass. India, 48(1): $24-28$. 